\title{
Author Correction: Updated annotation of the wild strawberry Fragaria vesca V4 genome
}

Yongping Li', Mengting $\mathrm{Pi}^{1}$, Qi Gao ${ }^{1}$, Zhongchi Liu $\mathbb{1}^{1,2}$ and Chunying Kang ${ }^{1}$

\section{Correction to: Horticulture Research (2019)6:61 \\ https://doi.org/10.1038/s41438-019-0142-6 \\ Published online 01 May 2019}

Since the publication of this article, the authors have noticed that the GeneIDs from new and original genome annotations don't match in Table S6, the correct Table S6 is given here.

The authors would like to apologize for this error.

Published online: 10 July 2019

Supplementary Information accompanies this paper at (https://doi.org/

10.1038/s41438-019-0174-y).

Correspondence: Chunying Kang (ckang@mail.hzau.edu.cn)

${ }^{1}$ Key Laboratory of Horticultural Plant Biology (Ministry of Education), College

of Horticulture and Forestry Sciences, Huazhong Agricultural University,

Wuhan, Hubei 430070, China

${ }^{2}$ Department of Cell Biology and Molecular Genetics, University of Maryland,

College Park, MD 20742, USA

() The Author(s) 2019

(c) (i) Open Access This article is licensed under a Creative Commons Attribution 4.0 International License, which permits use, sharing, adaptation, distribution and reproduction cc) in any medium or format, as long as you give appropriate credit to the original author(s) and the source, provide a link to the Creative Commons license, and indicate if changes were made. The images or other third party material in this article are included in the article's Creative Commons license, unless indicated otherwise in a credit line to the material. If material is not included in the article's Creative Commons license and your intended use is not permitted by statutory regulation or exceeds the permitted use, you will need to obtain permission directly from the copyright holder. To view a copy of this license, visit http://creativecommons.org/licenses/by/4.0/. 